\title{
POCZĄTKI MOWY U MAŁYCH DZIECI W KONCEPCJACH RZYMSKICH INTELEKTUALISTÓW, AUGUSTYNA I JANA CHRYZOSTOMA
}

Wartość słowa mówionego dla starożytnych była niepodważalna. Kariery retorów i filozofów, a także członków kleru, w cesarstwie rzymskim opierały się w wielu przypadkach na znajomości zasad retoryki. Kształceniu retoryczno-językowemu od okresu co najmniej VI wieku prz. Chr. przydawano zawsze wielkie znaczenie; czy jednak było ono takie również w odniesieniu do pierwocin kształtowania się mowy u dzieci, co przecież stanowi podstawę nie tylko dla zdobycia umiejętności retorycznych, ale i w ogóle egzystencji? Zagadnienie to omówię $\mathrm{w}$ odniesieniu przede wszystkim do okresu cesarstwa, bo rzecz ma dotyczyć tła zapatrywań na początki mowy w dziełach Jana Chryzostoma ${ }^{1}$.

Jeśli nie wiadomo, gdzie szukać początku, a w każdym razie istotnego zarysowania jakiegoś zagadnienia poruszanego w starożytności, należy zajrzeć do dzieł Platona i Arystotelesa. W tym miejscu wskażę tylko na kilka myśli Stagiryty w tym względzie, aby wykazać ewentualne zapożyczenia w dziełach Antiocheńczyka.

Zainteresowania fizjologią zaprowadziły Arystotelesa do konstatacji, iż aby wydać głos, trzeba wciągnąć i wypuścić powietrze, a w wydawaniu dźwięków bierze udział język. Dźwięki wywołuje uderzenie powietrza w tchawicę ${ }^{2}$. Są one modulowane przez język, którym kieruje dusza i dzięki temu tylko u człowieka mają one znaczenie ${ }^{3}$. Natura dała jednostce ludzkiej wyjątkowy

\footnotetext{
${ }^{1}$ Nie omawiam wszystkich wątków myśli greckiej i rzymskiej w dziedzinie początków mowy u dzieci, a jedynie wybrane, które dadzą wstępne wyobrażenie o zapatrywaniach, które mógł wykorzystać Jan Chryzostom.

${ }^{2}$ Por. De anima II 8420b-8421a.

${ }^{3}$ Por. Problemata III 31, 875b.
} 
język, gdyż służy on zarówno do postrzegania smaków, jak i artykułowania dźwięków, w czym uczestniczą także wargi i zęby:

„Mowa zaś jest artykulacją głosu za pomocą języka i samogłoski są wydawane przez głos i gardziel, spółgłoski zaś przez język i wargi; one razem składają się na mowę"4.

Mowa jest tylko właściwością człowieka, ale wyposażonego we wszystkie zmysły, gdyż głusi od urodzenia są, jak uważa filozof, zawsze niemi. Artykułowanie dźwięków ma na celu „wyższe zadowolenie”, „wyższe szczęście"s.

Wśród mniej lub bardziej przypadkowych uwag na temat mowy, nie ma dokładniejszych rozważań o jej kształtowaniu się u dzieci. Arystoteles podkreślał jedynie niedoskonałość początkowej fazy w życiu człowieka, co odbija się także na umiejętności mówienia. Małe dzieci i zwierzęta nie mogą wymówić wyraźnie głosek - dają więc znać nieartykułowanymi dźwiękami o swych potrzebach. Początkowo więc dziecko nie mówi, jedynie wydaje nieartykułowane dźwięki, później gaworzy, co dopiero jest wstępem do nauczenia się mowy $^{6}$. Niezbyt przychylna dzieciom jest także obserwacja, że:

„Małe dzieci, jak z jednej strony nie mają panowania nad innymi członkami [swoich ciał], tak z drugiej strony nie są w stanie z początku kierować swoim językiem; jest on niedoskonały i uzyskuje zupełną swobodę dopiero później. Toteż przez długi czas bełkoczą i seplenią"

Głosy dzieci są piskliwe, bo używają mało powietrza, a wtedy porusza się ono szybciej ${ }^{8}$.

Czasami niektóre dzieci wyprzedzają inne w szybkości uczenia się mowy, ale później wracają do stanu właściwego wiekowi. Proces uczenia się języka, zdaniem Arystotelesa, polega na tym, że dzieci najpierw słuchają i próbują skojarzyć znaczenie wypowiadanego słowa, przy czym uznaje, że niektóre niemowlęta nawet rozumieją to, co powtarzają. Następny etap to rozumienie tego, co mówią, ale czasami te umiejętności nie zbiegają się, i np. dopiero po zbudzeniu się (sen daje odpoczynek umysłowi) dziecko osiąga sukces w mówieniu: potrzeba jednak do tego także odpowiedniego ukształtowania narządu mowy9 . U ludzi, w przeciwieństwie do zwierząt, mowa doskonali się później, gdyż w stosunku do głosów wydawanych przez zwierzęta, jest bardziej skom-

${ }^{4}$ Historia animalium IV 9, 535a, thum. P. Siwek: Arystoteles, Zoologia, Warszawa 1982, 150; De partibus animalium II 16, 660a; III 1, 661b.

${ }^{5}$ Por. De anima II 8420b-8421a; Problemata X 38-40, 895.

${ }^{6}$ Por. Problemata XI 1, 899b; XI 14, 900a.

${ }^{7}$ Historia animalium IV 9, 536b, P. Siwek, s. 153.

${ }^{8}$ Por. Problemata XI 14, 900a.

${ }^{9}$ Por. tamże XI 27, 902a. 
plikowana i jej doskonalenie musi dłużej potrwać ${ }^{10}$. Filozof podkreśla fakt, że tylko człowiek wydaje wiele głosów i posługuje się różnymi narzeczami, bo umie wymówić wiele spółgłosek, a te z samogłoskami tworzą mowę ${ }^{11}$.

W ogólnych zapatrywaniach na dziecko Rzymianie okresu republiki kierowali się naukami Platona, Arystotelesa oraz epikurejczyków. Na temat kształtowania się mowy u dzieci pozostawili oni jednak tylko kilka oderwanych uwag $^{12}$. Recepcja poglądów szkoły epikurejskiej przez Lukrecjusza spowodowała dowartościowanie studiów nad psychiką dziecięcą. Ukazywał on m.in., jak niemowlęta, dbając o zaspokojenie swych potrzeb „,mówią” ruchami ciała i mimiką, co zastępuje im mowę. Poeta przekazuje też lub sam tworzy opinię, iż nie było u początków kształtowania mowy jakiegoś jednego źródła, „dawcy nazw", ale w naturalny sposób języki różnicowały się pod wpływem działania różnych grup ludzkich ${ }^{13}$. Natomiast Warron podkreślał, że dzieci posługują się swoistym językiem, a w wymowie dużą rolę pełni poprawnie ukształtowane uzębienie $^{14}$. Uznano także, że granicą wczesnego etapu rozwoju jest osiągnięcie około 3 roku życia swobody w posługiwaniu się mową, przedtem było to „dziecięce gadanie”, jak pisał np. Horacy ${ }^{15}$. O ile się orientuję, nie ma natomiast istotniejszych uwag na ten temat $\mathrm{u}$ Cycerona.

Więcej zainteresowania dzieckiem (częściowo może być to spowodowane obfitszą niż za republiki twórczością naukową i literacką oraz wyższym stopniem jej zachowania) przejawiali twórcy okresu cesarstwa. Nie tyle jednak były to analizy procesu powstawania mowy lub różnicowania się języków, co warunków, które zapewnią dziecku najwłaściwszą naukę w tym zakresie. Niańki, pedagogowie i inni opiekunowie małego dziecka (oczywiście także rodzice) mieli prezentować odpowiedni poziom kultury i obycia językowego. Kwintylian chciał nawet ustanowić jakby stałego kuratora nad niewolnikami domowymi, którzy stykali się z małymi dziećmi, aby ten korygował na bieżąco popełniane przez nich błędy ${ }^{16}$. Zwrócenie uwagi na konieczność dbania o jakość środowiska w zakresie języka wzięto przy tym m.in. z tradycji greckiej okresu hellenistycznego, kiedy to Chryzyp postulował, aby nawet niańki i piastunki kontaktujące się z dziećmi od chwili urodzenia miały... wykształce-

${ }^{10}$ Por. tamże XI 57, 904b.

${ }^{11}$ Por. tamże X 38-40, 895.

${ }^{12}$ Por. J. Jundziłł, Rzymskie zapatrywania na psychikę dziecka, „Antiquitas” 16 (1992) 15 i 18.

${ }^{13}$ Lucretius, De rerum natura V 1028-1090. G. Żurek (Titus Lucretius Carus, O naturze rzeczy, tłum. G. Żurek, Warszawa 1994, przyp. s. 285) wskazuje tu na analogię z Epikurem, który zakładał kształtowanie języka na potrzeby grup plemiennych, zob. Diogenes Laertios, Vitae philosophorum X 75-76.

${ }^{14}$ Por. Varro, De lingua latina VI 52; zob. Z. Danek, Starożytni o powstaniu mowy ludzkiej, „Meander” 41 (1986) 225-234.

${ }^{15}$ Por. Horatius, Ars poetica 158-160; Saturae II 3, 250-254.

${ }^{16}$ Por. Quintilianus, Institutio oratoria I 1, 4-5 i 11; Tacitus, Dialogus de oratoribus 28-29; Dio Chrysostomus, Oratio 33, 34; Plutarchus, Quaestiones convivales IX 2. 
nie filozoficzne ${ }^{17}$. Starania o jakość wysławiania się osób z otoczenia dziecka wypływało z przekonania, że dziecko uczy się mowy tylko poprzez naśladownictwo (np. Kwintylian). Jeden z dowodów na poparcie tezy, że nie jest to umiejętność wrodzona, stał się nawet toposem: opowiadano o wychowywaniu z rozkazu króla niemowląt bez kontaktu z mówiącymi, przez nieme niańki ${ }^{18}$. Nie trzeba więc specjalnych działań, aby nauczać małe dzieci języka. Wręcz przeciwnie, radość sprawiało słuchanie gaworzenia, a później dziecięcych prób wysławiania się i współuczestniczenie w takiej rozmowie przy użyciu „języka dziecięcego" i słów pieszczotliwych. Trzeźwe sądy mówiące, że powoduje to przychodzenie do szkół dzieci źle mówiących, z wadami wymowy, były nieliczne. U większości twórców przytrafiały się także sądy lekceważące „dziecięcą mowę" i w ogóle sposób wypowiadania się dzieci w okresie infantia i początkach pueritia $^{19}$.

Matki, ojcowie i dziadkowie, poza znajdowaniem przyjemności w praktykach mówienia po dziecięcemu, uważali podobno, iż w ten sposób łatwiej trafić do dziecka i że taki uproszczony język jest przyrodzony dzieciństwu ${ }^{20}$. Dwoistość postaw opartych z jednej strony na przekonaniu o konieczności dbania o „otoczenie językowe” małych dzieci, a z drugiej - pozwalaniu sobie na psucie mowy dziecka przymilną paplaniną, jest oczywista. Wytłumaczyć te dwie, niesprzeczne najwyraźniej dla Rzymian postawy, można różnymi okresami w życiu dziecka, do których się odnosiły. Wcześniejszy etap życia można było „stracić” na korzyść przyjemności zabaw z niemowlęciem, później jednak należało wymagać od niego coraz więcej, czemu miało służyć dobieranie opiekunów z wykształceniem i poprawną mową.

Bardziej ,naukowe” obserwacje prowadziły do ustalenia np. przez Pliniusza Starszego, że dziecko rzekomo mówi prawidłowo już od ok. pierwszego roku życia. Idąc za Arystotelesem Pliniusz podawał jednak przykłady w miarę poprawnej mowy nawet w wieku 6 miesięcy lub dopiero od kilku lat życia. Takie skrajne sądy i obserwacje wynikały nie tyle $\mathrm{z}$ obserwacji rzeczywistych faz rozwoju dziecka, co zamiłowania do relacji o rzeczach wyjątkowych, niecodziennych, odpisywanych z różnych zbiorów „osobliwości”21.

\footnotetext{
${ }^{17}$ Por. Quintilianus, Institutio oratoria I 1, 4.

${ }_{18}$ Por. tamże X 1, 10; zob. Herodotus, Historiae II 2, choć u niego historia dotycząca Psammetycha ma nieco inne znaczenie.

${ }^{19}$ Por. np. Seneca, Consolatio Marciae 5, 4; Consolatio Helviae 18, 5; Quintilianus, Institutio oratoria XII 10, 73; Statius, Thebaidae V 608-619, a także poglądy Musoniusa Rufusa, Favorinusa z Arelate i kilku innych, zob. K. Korus, Program wychowawczy Plutarcha z Cheronei, Wrocław Warszawa - Kraków 1978, 51; H.I. Marrou, Historia wychowania w starożytności, tłum. S. Łoś, Warszawa 1969, 325-340; J. Jundziłł, Wzorce i modele wychowania w rodzinie rzymskiej okresu III w. p.n.e. - III w. n.e., Bydgoszcz 2001, 218-228 i 234-239.

${ }^{20}$ Por. Fronto, Ad Antoninum Imperatorem I 3, por. J. Jundziłł, Rodzina rzymska $w$ czasach prosperity i przemian ideowych II wieku, Bydgoszcz 1996, 218-224.

${ }^{21}$ Plinius, Naturalis historia XI 112, 270.
} 
Kwintylian z kolei poprawnie zakwalifikował kwilenie jako początki nauki mowy i sposób na wzmacnianie narządów mowy ${ }^{22}$, a Petroniusz uznał, że w okresie karmienia naturalnego dziecko jako pierwsze wymawia sylaby „mu” i „ma”23, zaś Fronton - „da”, także jako wyraz przemożnej ciekawości małego wnuka $^{24}$. Z kolei Plutarch uważał ,a" za pierwszą głoskę wymawianą przez dziecko $^{25}$. Gaworzenie miało być nie ćwiczeniem narządów mowy, ale sygnałem dla opiekunów odnośnie konieczności zaspokojenia potrzeb niemowlęcia. Mylenie dźwięków i sylab, dziecięce „bełkotanie” sprawiało przy tym mnóstwo przyjemności rodzicom i opiekunom ${ }^{26}$. W dodatku Kwintylian oraz inni retorzy i moraliści, jak np. Seneka, zakładali, że należy nauczać najpierw greki, gdyż małe dziecko i tak samo przyswoi sobie łacinę bez wysiłku ${ }^{27}$. W ciągu rozwoju myśli rzymskiej nie wytworzono więc bardziej zaawansowanych zapatrywań na początki mowy dzieci, ale nagromadzono wystarczająco dużo obserwacji, by następcy mogli z nich korzystać ${ }^{28}$.

Ojcowie Kościoła nie odbiegali od tego typu poglądów ${ }^{29}$. Jednym z nielicznych, którzy zainteresowali się mechanizmem powstawania mowy i jej początkami, był Tertulian. Krytykował on m.in. doświadczenie przeprowadzone na rozkaz faraona Psammetycha $\mathrm{z}$ wychowaniem niemowląt przez mamkę pozbawioną języka. Według niego niańka nawet wtedy mogła bełkotać, a niemowlęta naśladując ją przypadkowo wypowiedziały słowo frygijskie „bekos”, więc nie dowodzi to wrodzoności mowy, ani pierwszeństwa języka Frygów ${ }^{30}$. Przy okazji Tertulian zauważa, że w artykulacji mowy uczestniczą wargi, język i krtań, czyli podobnie, jak uczył Arystoteles. W innym miejscu podkreśla rolę nauki mowy w rozwoju dziecka: jest to niemożliwe bez przysłuchiwania się rozmawiającym dorosłym, gdyż ta umiejętność nie jest dzieciom wrodzona, choć kwilenie to naturalne odgłosy wydawane przez niemowlę, a pierwsze

${ }^{22}$ Por. Quintilianus, Institutio oratoria I 1, 21; podobnie Suetonius, Tiberius 6; Apuleius, Metamorphoses VI 4.

${ }^{23}$ Por. Petronius, Satiricon 57: „tu lacticulosus, nec mu nec ma argutas”.

${ }^{24}$ Por. Fronto, Epistolae ad amicos I 12.

${ }^{25}$ Plutarchus, Quaestiones convivales IX 2.

${ }^{26}$ Por. Iuvenalis, Saturae 5, 141-145; Statius, Thebaidae V 608-619; Ausonius, Parentalia X 3-4.

${ }^{27}$ Por. Quintilianus, Institutio oratoria I 1, 12; Seneca, Epistola 33, 6-7.

${ }^{28}$ Por. J. Jundziłl, Specyfika wieku dziecięcego w oczach Rzymian okresu cesarstwa a wychowanie $w$ rodzinie, ,Studia Pedagogiczne” 18 (1992) 7-21; tenże, Wzorce i modele wychowania, s. 220-221; tenże, Rodzina rzymska w czasach prosperity, s. 204-205.

${ }^{29} \mathrm{~Np}$. Grzegorz z Nyssy pisze (De pauperibus amandis I 1, PG 46, 453, thum. T. Sinko: Św. Grzegorz z Nyssy, Wybór pism, Warszawa 1963, 166) o „sepleniących chłopcach” przychodzących do szkoły.

${ }^{30}$ Nawiązanie do historii opowiedzianej przez Herodota (Historiae II 1-3). 
jego słowa to „tata”, „mama” ${ }^{31}$. Choć więc wiele sądów Tertuliana było niechętnych dzieciom, to gdy potrzebował argumentów w prowadzonych polemikach teologicznych nierzadko sięgał również po repertuar toposów opisujących zachowania niemowląt ${ }^{32}$. Natomiast nie można o to posądzać Minucjusza Feliksa, który, podobnie jak Fronton, ze wzruszeniem i sympatią wspominał używanie przez małe dzieci swoistego języka ${ }^{33}$, już jednak Cyprian odwraca się od tego realistycznego stanowiska, aby kwilenie niemowląt ukazać jako formę modlitwy do Boga ${ }^{34}$, a Hilary kwilenie nowo narodzonego Chrystusa raz ma za „upokorzenie naszej (ludzkiej) natury”, a zaraz potem za dowód wielkości, mimo ograniczeń ${ }^{35}$. Dla innych Ojców Kościoła była to jednak oznaka niemowlęctwa dająca bliskim dużo radości ${ }^{36}$.

Wcześniej na Wschodzie Orygenes wspominał obecny w literaturze niechrześcijańskiej motyw rozmowy z dziećmi po dziecięcemu, zmuszania się dorosłego do specyfiki tego wysławiania w uproszczony sposób. Odnosi to do dwulatka, który jego zdaniem inaczej nie zrozumie dorosłego mówiącego „poważnie”, trzeba więc zniżyć się do jego poziomu:

„Zwróć uwagę, że my, dorośli ludzie, w rozmowie z dziećmi zmieniamy nazwy przedmiotów: dla dzieci specjalnym wyrazem określamy chleb, innego wyrazu używamy na określenie napoju. Nie posługujemy się językiem ludzi dorosłych, takim, jakiego używamy w stosunku do dorosłych rozmówców, lecz korzystamy z jakiegoś innego języka, dziecinnego i niemowlęcego. Również mówiąc dzieciom o ubraniu nazywamy je inaczej, tak jakbyśmy tworzyli dziecinne wyrazy. Czyż wtedy nie jesteśmy dorośli? Czyż słuchając, jak rozmawiamy z dziećmi, powie ktoś: «Ten starzec zgłupiał, ten człowiek

${ }^{31}$ Por. Tertullianus, Ad nationes I 8, 2, CCL 1, 21, thum. E. Stanula, PSP 29, 54: „Psammetych sądził, że doświadczalnie odkrył pierwsze przekonanie dotyczące rodzaju ludzkiego. Albowiem, jak mówią, niemowlęta zaraz po urodzeniu przekazał, w oparciu o umowę społeczną, na wychowanie mamce, którą pozbawił języka, by całkowicie odcięte od mowy ukształtowały swoją mowę nie na podstawie słuchu, lecz by ze siebie samych wydobywając głos, oznaczyły ten pierwszy naród, którego język podyktowałaby sama natura. «Beccos» było pierwszym słowem, co oznacza u Frygów chleb, stąd też uważa się Frygów za pierwszy naród"; Adversus Judaeos 9; De carne Christi 2; 4-5; 20; Contra Marcionem III 13, 2-5; IV 23, 5-6; 25, 5; De anima 19, 25 i 39; Adversus Valentinianos 2.

${ }^{32}$ Por. M. Kosznicki, Ksztatcenie $i$ wychowanie w literaturze zachodniego chrześcijaństwa od I do IV wieku, Gdańsk 1999, 48.

${ }^{33}$ Por. Minucius Felix, Octavius 2, 2. CSEL 2, 4, tłum. M. Szarmach, PSP 44, 21 : „Dzieci, owe baraszkujące niewinnie brzdące, tak rozkoszne wtedy, gdy ledwie wymawiają półsłówka i szczebioczą tym swoim łamanym językiem".

${ }^{34}$ Por. Cyprianus, Epistola 64, 6, 2, CCL 3C, 425, tłum. W. Szołdrski, PSP 1, 217: „, [...]odnośnie dzieci i noworodków. Te tym bardziej zasługują na naszą pomoc i miłosierdzie Boga, ponieważ przy swym urodzeniu nic innego nie czynią, tylko proszą kwileniem i płaczem".

${ }^{35}$ Por. Hilarius Pictaviensis, De Trinitate II 24 i 27, SCh 443, 316 i 318, thum. E. Stanula, PSP 64, 93-94.

${ }^{36}$ Por. Zeno Veronensis, Tractatus I 24, 1-2; II 9, 11 i 11, 28; Hilarius Pictaviensis, Tractatus super Psalmum 13, 5; zob. Kosznicki, Ksztatcenie $i$ wychowanie, s. 56. 
zapomniał o swojej brodzie, o swym dojrzałym wieku»? Czy raczej z uwagi na sytuację zgodzi się na to, aby w rozmowie z dziećmi nie mówić językiem ludzi starszych i dorosłych, ale językiem dziecinnym? Otóż i Bóg rozmawia z dziećmi. Zbawiciel stwierdza: «Oto ja i dzieci moje, które dał mi Bóg» (Hbr $2,13)$. Do starca rozmawiającego po dziecięcemu albo - powiem z przesadą - w sposób niemowlęcy, można powiedzieć: «Przystosowałeś się do swego syna, przyjąłeś sposób bycia niemowlęcia, dostosowałeś się do sytuacji»" ${ }^{\text {37 }}$.

Orygenes $^{38}$ i Laktancjusz podkreślali także niedoskonałość mowy dzieci, niewyraźny sposób wysławiania się, a nawet jąkanie, co wskazuje na recepcję myśli Arystotelesa, którego właśnie interesowało zjawisko jąkania, tłumaczone m.in., jak u Laktacjusza, niewykształceniem lub patologiami rozwojowymi uzębienia $^{39}$. Natomiast Hieronim w retorycznym uniesieniu pisał, iż chciałby, aby małe dziecko u początków mowy nuciło „Alleluja”. On także kontynuuje tradycję antyczną przestrzegając przed złym wpływem otoczenia na kształtującą się mowę i umysłowość dziecka. Najwyraźniej jednak chce świadomie uczyć małe dziecko języka, co ma się odbywać przy okazji poznawania ,świętych imion", czyli imion postaci biblijnych ${ }^{40}$.

Ambroży uznał, że brak zdolności mowy u niemowląt wiąże się z niewykształceniem odpowiednich organów, języka, zębów, warg i gardła, a w ogóle ten, kto nie zna Pisma Świętego jest jak dziecko nie umiejące mówić, czyli problem kształtowania się mowy u dzieci zajmuje go tylko jako figura retoryczna. Podstawową rolę w mówieniu pełni język i zęby, a brak tych ostatnich czyni niemowlę niemym. Fragment Hexaemeronu poświęcony temu zagadnieniu jest poetycką i retoryczną trawestacją dzieł Arystotelesa, zwłaszcza w zaakcentowaniu roli rozumu w kształtowaniu języka. Dzięki temu człowiek nie tylko wydaje dźwięki, ale i posługuje się mową. Cały ten wywód jest jednak

${ }^{37}$ Origenes, In Jeremiam hom. 18, 6, SCh 238, 200, thum. S. Kalinkowski, PSP 30, 157-158; podobnie, ale krócej: Contra Celsum IV 71.

${ }^{38}$ Por. tenże, In Numeros hom. 26, 3, 1, SCh 461, 236, tłum. S. Kalinkowski, PSP 34/1, 256: „Wszelkie wypowiedzi należy oceniać nie tylko na podstawie wypowiadanych słów, lecz zwłaszcza trzeba brać pod uwagę również osobę, która je wypowiada. Jeśli na przykład przemawia dziecko, nastrajamy nasze umysły do słuchania słów dziecięcych i po słowach tych nie spodziewamy się nic ponad to, co mogło myśleć dziecko. Jeśli zaś osobą przemawiającą jest mężczyzna, od razu zwracamy uwagę, czy Jego słowa są godne mężczyzny”; In Jeremiam hom. 1, 8, SCh 232, 214, PSP 30, 29: „I jak ja zadaję sobie trud ucząc się mówić na sposób dziecinny, kiedy z dziećmi rozmawiam, bo nie potrafię, że tak powiem, mówić po dziecinnemu, a jako człowiek dorosły zmuszam się do rozmowy z małymi dziećmi, tak samo i Zbawiciel, który jest w Ojcu".

${ }^{39}$ Por. Lactantius, Divinae Institutiones 26, 3; De opificio Dei 10.

${ }^{40}$ Por. Hieronymus, Epistola 107, 1 i 4, CSEL 55, 291 i 295, thum. J. Czuj: Św. Hieronim, Listy, II, Warszawa 1953, 401 i 403-405: „by uwierzył, że wnuczka kapłana Albina narodzi się z obietnicy matki, że w obecności dziadka i ku jego uciesze niezdarny jeszcze język maleństwa będzie nucił Chrystusowe «Alleluja»". 
oderwany od realiów towarzyszących nauce mowy przez dziecko na korzyść pochwały rozumności człowieka, która prowadzi go do Boga ${ }^{41}$.

Na tym tle rekonstrukcje zachowań i odczuć niemowlęcia w Wyznaniach Augustyna są wyjątkowe. Najpierw gestami i nieartykułowanymi głosami, dzięki wrodzonym (?) zdolnościom niemowlę usiłuje dać znać, o co mu chodzi. Jest to metoda prób i błędów - kojarzenie dźwięków i pożądanych efektów osiąganych za ich pomocą. Następny etap to łączenie dźwięków z konkretnymi sytuacjami, przedmiotami i ich nazwami, a więc mimowolna nauka słów. Zaznacza, że nie dorośli uczyli go mówić w jakiś logiczny sposób, a jedynie potrzeba powodowała konieczność wypowiadania konkretnych nazw. Mowa i język wprowadziły go w ludzką społeczność. Dodatkowe cierpienia spowodowała jednak nauka greki jeszcze przed ugruntowaniem znajomości łaciny. I tak jednak greka wraz z początkami matematyki była dla niego udręką ${ }^{42}$. W innym miejscu mówił, że dziecko uczy się mowy poprzez naśladowanie, a nie poznawanie najpierw zasad nią rządzących. Są one (zasady gramatyki) jednak potrzebne dlatego, że dziecko nie żyje w sterylnym językowo środo-

${ }^{41}$ Por. Ambrosius, Hexaemeron VI 66-69, PL 14, 284-286, thum. W. Szołdrski, PSP 4, 221 222; Epistola 77, 9; zob. też Prudentius, Peristephanon X 3; Commodianus, Instructiones I 16; Kosznicki, Ksztatcenie i wychowanie, s. 37-65.

${ }^{42}$ Por. Augustinus, Confessiones I 8 i 13, CCL 27, 7 i 11-12, tłum. Z. Kubiak: Św. Augustyn, Wyznania, Kraków 1999, 34-35 i 40-41: „Nie byłem niemowlęciem. Gadałem. Byłem już chłopcem. To już pamiętam. Potem zrozumiałem, w jaki sposób nauczyłem się mówić. Dorośli nie uczyli mnie poszczególnych słów w takiej określonej kolejności, jak później uczyli liter. To było tak, że ja sam dzięki rozumowi, jakim obdarzyłeś mnie, Panie, usiłowałem jękami, najróżniejszymi dźwiękami, gestami wyrazić moje uczucia, aby spełniano moja wolę; nie udawało się wyrazić wszystkiego ani wyrazić tego wobec wszystkich, do których się zwracałem. Zachowywałem w pamięci dźwięk, jakim oni daną rzecz nazywali, i gdy widziałem, że pod wpływem takiego dźwięku poruszają się w pewnym kierunku, pojmowałem, że nazywają daną rzecz tym właśnie dźwiękiem, który wypowiadają wtedy, kiedy chcą na nią wskazać. Tę ich intencję poznawałem z ruchów ciała, z czegoś, co jest jakby naturalną mową wszystkich ludzi, wszystkich ludów, polegającą na wyrazie twarzy, poruszeniach oczu, na różnych gestach, jak też na samym brzmieniu głosu, które ujawnia nastawienie wewnętrzne człowieka w prośbach, stwierdzeniach, odmowach i poleceniach. Stopniowo rozpoznawałem, jakie rzeczy oznaczane są. słowami, które się często pojawiały w określonych miejscach różnych zdań, a opanowawszy wymowę tych słów, wyrażałem za ich pomocą własne życzenia. Odtąd mogłem wymieniać znaki życzeń z ludźmi, pośród których żyłem. Taką to drogą wszedłem głębiej w burzliwe życie ludzkiej społeczności, zależny od władzy rodziców i innych dorosłych [...]. Do dziś nie mogę zrozumieć, dlaczego język grecki, gdy uczyłem się go w dzieciństwie, budził we mnie tak wielką odrazę! Lubiłem lekcje łacińskie - nie te początkowe, lecz lekcje poświęcone studiowaniu literatury. Początkowe lekcje, podczas których uczyłem się czytać, pisać i liczyć, wcale nie mniejszą były dla mnie udręką niż wszystkie godziny greckie. Z czego to wynikało? Oczywiście z grzechu i z głupoty. Ciałem byłem, wiatrem, który gna gdzieś, a nie wraca. O ileż lepsze, bo pewniejsze, były tamte początki nauki. $Z$ nich mam to, co do dziś przynosi mi pożytek: że i przeczytać potrafię, i napisać, co chcę [...]. Grzeszyłem w latach chłopięcych, gdy niedorzeczności ceniłem wyżej od rzeczy pożytecznych. Co mówię! Jedne kochałem, drugich nienawidziłem. Jeden i jeden - dwa; dwa i dwa - cztery. Jakże nienawistna była dla mnie ta śpiewka". 
wisku, ale styka się także z mówiącymi niepoprawnie. Pojawia się przy tym obserwacja, że ludzie z miast mówią poprawniej niż ze wsi, może z powodu większych szans usłyszenia właściwej wymowy ${ }^{43}$.

Zatem opis początków nauki mowy, o ile się orientuję, jest wyjątkowo osobisty, i bez naleciałości wynikłych z lektur dzieł klasycznych. Pobrzmiewa w nim jednak stoicka nuta niechęci do dziecka (oczywista w odniesieniu do całości charakterystyki dzieciństwa). Nauka mowy i języka ma przecież utylitarny podtekst zaspokojenia potrzeb, i to nie duchowych, ale cielesnych. Nie ma u Augustyna czułostkowych obrazków gruchania rodziców z niemowlęciem, ale wizerunek relacji klient (dziecko) - dysponent dóbr (rodzice, opiekunowie). Niemowlę zrobi wszystko, aby otrzymać to, czego pragnie poprzez wydawanie nieartykułowanych dźwięków i ruchami ciała. Augustyn w swej niechęci do tego okresu jest więc bliski stoikom rzymskim i Tertulianowi, choć brak przy tym jasno określonych powodów owej niechęci, poza - jak uważa - ogólną skłonnością dzieci do bezrozumnego grzeszenia.

\section{III}

Również Jan Chryzostom interesował się małymi dziećmi, a w każdym razie w wypowiedziach o nich lubił stosować obrazowanie z wykorzystaniem figur i porównań budowanych w oparciu o tezę, reprezentowaną przez część moralistów rzymskich, że małemu dziecku nie dostaje rozumu, a wszystko co robi, jest miałkie i mało ważne do tego stopnia, że dopiero wychowawcy i nauczyciele czynią z niego jednostkę wartościową. W jego pismach spotykamy wiele wtrąceń w rodzaju: bezrozumne gadanie, bajki dzieci, dziecinne igrasz$\mathrm{ki}^{44}$. Poczynił jednak także niemało pozytywnych obserwacji z zachowań najmniejszych dzieci i opieki nad nimi oraz nawiązań do ewangelicznej apoteozy maluczkich. Oznacza to, że i kształtowanie się mowy u dzieci znajdowało się w orbicie jego zainteresowań, choć w dość ograniczony sposób. Wyznacza na

${ }^{43}$ Por. tenże, De doctrina christiana IV 3, 4-5, CCL 32, 119, tłum. J. Sulowski, PSP 22, 101: „Ponieważ dzieci uczą się mowy przez samo naśladowanie mówiących, dlaczego nie można by zostać oratorem nie ucząc się sztuki wymowy, lecz nabywając jej wyłącznie przez czytanie, słuchanie i w miarę możliwości naśladowanie? Czyż słuszności tego nie potwierdzają przykłady? Przecież znamy wielu mówców nie znających zasad retorycznych, a mimo to bieglejszych niż ci, którzy tego się uczyli, ale nikogo, kto nie czytałby i nie słuchał dysput albo wystąpień ludzi wymownych. I dzieci nie potrzebowałyby gramatyki podającej prawidła poprawnej wymowy, gdyby mogły wzrastać i żyć pośród ludzi mówiących poprawnie. Nie znając bowiem błędów nawet z nazwy, a słysząc z cudzych ust niepoprawne wyrażenie, poprawialiby błędnie mówiących, a przyzwyczajenie do poprawności chroniłoby ich samych od błędów, podobnie, jak ludzie z miasta poprawiają wieśniaków, choć sami nie potrafią czytać".

${ }^{44}$ Por. In epistolam ad Romanos hom. 7, 3; In Matthaeum hom. 28, 3; 33, 4; 43, 5; 47, 4. 
przykład mowie znaczącą rolę w rozwoju człowieka i wychowaniu dzieci, ale zbyt wielu konkretów na ten temat u niego nie $\mathrm{ma}^{45}$. O mowie zaś pisał:

„Nic bowiem nie jest tak miłe Bogu, jak życie dla pożytku ogółu. Dlatego dał nam Bóg mowę, ręce, nogi, silne ciało, serce, rozum, abyśmy używali wszystkich tych darów dla naszego zbawienia i dla pożytku bliźnich. Mowa bowiem służy nam nie tylko do śpiewania hymnów i składania dziękczynienia, lecz jest również przydatna do nauczania i upominania. Jeśli używamy jej do tego, naśladujemy Pana, a jeśli do rzeczy przeciwnych - wtedy diabła [...]. Powiedziałem, że nasz język jest ręką, która obejmuje nogi Boga"46.

Jan Chryzostom podkreślał, iż języka trzeba używać świadomie, dusza, rozum i serce kierują nim pod wpływem wiary i pouczeń z niej płynących ${ }^{47}$. Poskramianie języka przed pleceniem głupstw ,jak stare baby” jest obowiązkiem chrześcijan, przy czym zauważa, że mamy tu do czynienia z prostą zależnością: jaka moralność, taki język ${ }^{48}$. Kalają język przekleństwa, krzywoprzysięstwa, a głos sprawiedliwych jest inny od głosu nierządnych ${ }^{49}$. Należy przemawiać według sposobu Chrystusa, bo inaczej, mówi kaznodzieja, nie zwróci on na ciebie uwagi, złośliwie porównując Boga do rzymskiego prawnika, który rozumie tylko łacinę ${ }^{50}$.

Z powodu licznych zapytań wiernych Jan Złotousty wyjaśniał także, dlaczego Apostołowie po chrzcie mówili różnymi językami (Dz 19, 2-6), a teraz nawet sprawiedliwi nie dostępują tej łaski. W odpowiedzi podkreślał, że Bóg nie odnosi się bynajmniej z mniejszym szacunkiem do ochrzczonych żyjących teraz; tamci musieli zostać wsparci tym przywilejem, bo przemawiali do ludzi

${ }^{45}$ Por. In Matthaeum hom. 58, 2-3; 71, 4; De inani gloria et liberorum educatione 28.

${ }^{46}$ In Matthaeum hom. 78, 3, PG 58, 714-715, tłum. J. Krystyniacki, ŹMT 23, 421.

${ }^{47}$ Por. In Genesim hom. 4, 3; In Matthaeum hom. 42, 1.

${ }^{48}$ Por. In Matthaeum hom. 2, 5; 32, 1; 51, 5-6.

${ }^{49}$ Por. tamże 68, 4.

${ }^{50}$ Por. tamże 78, 4, PG 58, 716, ŹMT 23, 422-423: „Mów więc tak jak On, a staniesz się w tym Jemu podobny, o ile tak można, będąc człowiekiem [...]. Naucz swą duszę, by ukształtowała usta na podobieństwo ust Chrystusa. Ona zna tę sztukę, jeśli zechce, jeśli nie będzie gnuśna, może uczynić coś podobnego. «A jak, powiesz, robi się takie usta? Jakimi farbami? Z jakiego materiału»? $\mathrm{Z}$ żadnych farb i z żadnego materiału, tylko cnotą, skromnością i pokorą. Przyjrzyjmy się, w jaki sposób usta stają się szatańskie, abyśmy nigdy nie uczynili naszych takimi. Jak więc się stają? Poprzez przekleństwa, złorzeczenia, zawiść, krzywoprzysięstwa. Gdy ktoś mówi jego słowami, ten zachowuje jego język. Czyż więc otrzymamy jakieś przebaczenie, a raczej jak wielką karę będziemy znosić, jeśli nie będziemy zważać na to, że język, z którego pomocą zostaliśmy uznani za godnych dotykania Ciała Pańskiego, wygłasza szatańskie słowa? Nie pozwalajmy na to, ale dołóżmy wszelkich starań, by go nauczyć, aby naśladował swego Pana. Jeśli go tego nauczymy, wtedy on postawi nas z wielką ufnością przed sądem Chrystusa (por. 2Kor 5, 10). Kto nie będzie umiał tak mówić, tego sędzia nawet nie zechce słuchać". 
nie znających jeszcze zasad wiary i nieświadomych roli Ducha Świętego: był to znak dla niewiernych, by uwierzyli ${ }^{51}$.

Wychowanie od niemowlęctwa, także w mowie, to wielkie zadanie rodziców, zwłaszcza matki, za co otrzymają wielkie nagrody w postaci dobrych dzieci. Rodzice i wychowawcy powinni zaczynać w tym procesie od elementów prostych, prowadzących do całości: chcąc zostać filozofem, trzeba zacząć od nauki pisania liter ${ }^{52}$. Chryzostom nie ustrzegł się jednak przy tym przed wykorzystywaniem toposu akceptującego „mowę dziecinną”, stosowaną w kontaktach z małymi dziećmi:

„Bo jeżeli ojciec nie zważa na swą godność, lecz sepleni ze swymi małymi dziećmi i pokarmu, potraw, kubków nie nazywa nazwami greckimi, lecz jakimś językiem dziecinnym i barbarzyńskim, to tym bardziej czyni to Bóg. I zniżając się do ludzi gani ich przez usta proroków"53.

Także i w innym miejscu podkreślał swoistość mowy małych dzieci (szczebiotanie) najwyraźniej zakładając, że brak poprawności mowy u dzieci jest sprawą naturalną ${ }^{54}$. Nie przeszkadzało to kaznodziei, gdyż nie wahał się przytoczyć zdania swej matki, która samotnie musiała parać się jego wychowaniem:

„Dlatego, gdy byłeś mały i jeszcze mówić nie umiałeś, kiedy to dzieci najwięcej rozweselają rodziców, sprawiałeś mi wiele pociechy" ${ }^{55}$.

Uważał jednak najwyraźniej, że naśladowanie dorosłych rozwiąże wszelkie problemy: wystarczy wzorem wcześniejszych zaleceń zadbać o właściwy dobór otoczenia, niańki, pedagogów, a także poziom wykształcenia dzieci niewolniczych, aby osiągnąc szybko znaczące rezultaty. Jego optymizm sięga tak daleko, że pozwala wierzyć, iż w nieco późniejszym okresie rozwoju dziecka wystarczą zaledwie dwa miesiące do korekty złego wysławiania się, poprzez zastosowanie pouczeń i nadzór nad rodzajem kontaktów dziecka, choć zdrowo rozsądkowo zakłada, że oddziaływania w tym kierunku muszą być prowadzo-

\footnotetext{
${ }^{51}$ Por. De sancta pentecoste hom. 1, 4, PG 50, 453-463.

${ }^{52}$ Por. In epistolam I ad Timotheum hom. 9, 2; In Matthaeum hom. 11, 7-8; 49, 6.

${ }^{53}$ In epistolam ad Titum hom. 3, 2, PG 62, 678, tłum. T. Sinko: Jan Złotousty, Homilie na listy pasterskie św. Pawła i na list do Filemona, Kraków 1949, 329.

${ }^{54}$ Por. In Matthaeum hom. 67, 1, PG 58, 633, ŹMT 23, 301: „I dobrze rzekł: «Z ust». Ich słowa: «Z ust niemowląt i ssących zgotowałeś sobie chwałę»? (Ps 8, 3, LXX) nie były wyrazem ich myśli, lecz Jego moc kierowała ich niedojrzałym językiem. Było to także figurą pogan, którzy od razu szczebiocąc głosili wielkie rzeczy ze zrozumieniem i wiarą. Wynikała stąd niemała pociecha dla apostołów. Aby się nie obawiali, w jaki sposób, będąc ludźmi prostymi, będą mogli głosić tę naukę, dzieci zawczasu pozbawiają ich wszelkiej obawy, pokazując, że Ten, który podsunął tę pieśń dzieciom, również i im podda to, co będą mieć mówić (por. Mt 10, 19-20)".

${ }^{55}$ De sacerdotio I 2, SCh 272, 68, thum. W. Kania, BOK 1, 45.
} 
ne konsekwentnie przez wszystkich domowników ${ }^{56}$. Istotne są przy tym częste ćwiczenia:

„Zważ więc, że u pogan wielu ludziom jąkającym się, poprawiono ułomny język przez częste ćwiczenie" ${ }^{57}$.

Być może jest to aluzja do postępowania Demostenesa.

Przedstawione wyżej zapatrywania, przynajmniej częściowo, nie odbiegają zbyt daleko od ustaleń współczesnej psychologii. Według bowiem psychologów rozwojowych formy poprzedzające mowę to krzyk, który wyładowuje napięcie, sygnalizuje głód, senność oraz jest wynikiem konfliktów z opiekunami i rodzeństwem; w mniejszym zakresie powodowany jest poczuciem krzywdy i strachem. Już w trzecim miesiącu życia niemowlę wie, że krzyk powoduje reakcję opiekunów, 3-5 miesięczne, że zwrócenie uwagi na nie. W 2 miesiącu dziecko potrafi różnicować krzyk zależnie od potrzeb. Jego natężenie wzrasta wraz z rozwojem krtani, a krzykowi towarzyszą różne ruchy ciała, dostosowane do okoliczności. Wbrew niektórym zaleceniom wychowawczym brak reakcji na krzyk powiększa tylko jego zakres, podobnie jak błędne rozpoznanie potrzeb dziecka sygnalizowanych krzykiem.

Następnym etapem są dźwięki wybuchowe (łapanie powietrza przy oddychaniu, ,h” przydechowe, przypadkowe odgłosy przy ćwiczeniu formujących się organów mowy) i gaworzenie. Występuje przewaga samogłosek (od wymawianych przodem do tylnych), spółgłoski pojawiają się w kolejności odwrotnej. Związane jest to z fazami rozwoju organów mowy. Gaworzenie to najczęściej dźwięki „da”, „ma”, ,agh”, ćwiczenia tego typu trwają najczęściej do 12 miesiąca życia, ale mogą się przedłużać jeśli są skuteczne. Nie jest ono przygotowaniem do wymowy konkretnych wyrazów, ale ćwiczeniem narządów mowy.

Współczesna psychologia rozwojowa uznaje gotowość niemowlęcia do porozumiewania się mową w 12-18 miesiącu życia. Poprzedza ten etap mowa gestów i naśladowanie wszystkich elementów otaczającego środowiska. Poprawne wzory w tym względzie są bardzo ważne, gdyż zaobserwowano nawet naśladowanie jąkania. Przyspiesza naukę kojarzenie wizerunku przedmiotu lub samego przedmiotu i słowa, dzięki temu niemowlę szybciej wychodzi z fazy ,papugi”, czyli powtarzania wyrazów bez zrozumienia treści.

${ }^{56}$ De inani gloria et liberorum educatione 32-33, SCh 188, 124, BOK 19, 85: „Zwróć uwagę i matce, aby dawała chłopcu te same nauki, również wychowawcy i służącemu. Niech strzegą i uważają, aby żadne złe słowo nie wymknęło się z ust syna. Nie myśl, że ten trud zajmie dużo czasu. Gdy od początku wystąpisz stanowczo i roztoczysz straż, wystarczą dwa miesiące, a wszystko będzie w porządku. Przyzwyczajenie do dobrego stanie się drugą naturą".

${ }^{57}$ In Matthaeum hom. 17, 7, PG 57, 263, ŹMT 18, 224. 
Na tym etapie rozwoju nie mamy do czynienia z generalizacji, skojarzenia są konkretne.

Ważne w nauce mowy są motywy: jeśli dziecko zauważa, że mowa ciała, gestów i gaworzenie wystarcza dla osiągnięcia celu, uczy się języka wolniej. Głównym motywem jest potrzeba informacji o otoczeniu, bardziej zrozumiały dla opiekunów rozkaz - żądanie. Nauka nie postępuje regularnie, przerwy, chwilowy brak postępów spowodowany jest zajęciem się ćwiczeniami innych czynności, np. chodzenia. Rozwój mowy zgodny jest także z ogólnym rozwojem organizmu dziecka, np. powiększaniem objętości płuc, doskonaleniem organów mowy.

Zadania stawiane sobie w procesie nauki mowy przez dziecko i dziecku to rozumienie innych, tworzenie słownika i zdań oraz kształtowanie i poprawianie wymowy. Początkowe uczenie się słów to „paplanina”, bo dziecko potrafi reprodukować słowo, ale nie rozumie jego znaczenia, co dotyczy zwłaszcza nazw cyfr, łatwo opanowywanych, ale bez zrozumienia, co pod nazwami tkwi. E. Hurlock uważa, że do 18 miesiąca życia większość wypowiedzi dziecięcych jest niezrozumiała, względną poprawność dzieci osiągają w trzecim roku życia. W drugim roku poprawia się stopniowo wymowa, a po trzecim chłopcy częściej naśladują ojców, choć ci rzadziej niż matki przebywają w środowisku rodzinnym. Wprowadzanie dwujęzyczności w wieku 3-5 lat opóźnia rozwój mowy, a nawet sprawność myślenia, gdyż dziecko nie ma pewności, które słowa obu języków są poprawne. Pogarsza to sprawność, opóźnia rozwój języka ojczystego ${ }^{58}$.

Jak więc widać, starożytni, a zwłaszcza św. Augustyn, mieli dobre podstawy do właściwego podejścia do nauki mowy u małych dzieci, ale na ogół nie wychodzili poza hasło dbania o jakość otoczenia. Moraliści, filozofowie, Ojcowie Kościoła pisali i głosili swe poglądy w oparciu o wyrafinowane reguły retoryczne, które poznawali i ćwiczyli przez całe życie. Nie przeszkadzało to jednak w lekceważeniu początków, właśnie nauki mowy. Niestety nie odbiega od tej reguły i Jan Chryzostom. Czyżby więc mniej lub bardziej uświadamiana postawa lekceważąca początkową fazę rozwoju dziecka miała aż tak silny wpływ na sposób myślenia, iż przysłaniała oczywistą prawdę o konieczności świadomej nauki mowy? Trzeba też o to spytać współczesnych, skoro ciągle rozmawiamy z maluchami „po dziecinnemu”, sobie robiąc przyjemność, ale dziecku szkodę.

${ }^{58}$ Por. E. Hurlock, Rozwój dziecka, tłum. B. Hornowski - S. Kowalski - B. Rosemann, Warszawa 1960, 249-298; Z. Włodarski, Rozwój wyższych czynności układu nerwowego dziecka, w: Psychologia rozwojowa dzieci i młodzieży, red. M. Ziemska, Warszawa 1966, 144-147, 177-181; I. Kurcz, Psychologia języka i komunikacji, Warszawa 2005. 
THE BEGINNINGS OF SPEECH IN SMALL CHILDREN IN THE CONCEPT OF ROMAN INTELLECTUALS, AUGUSTINE AND JOHN CHRYSOSTOM

\section{(Summary)}

The paper is a preliminary outline of the history of views on the teaching of speech to children in ancient thinkers, especially Aristotle, Romans from the times of Republic and Empire, as well as the Church Fathers, especially Western, including Augustine in order to determine what John Chrysostom wrote and said on that subject. All the above-mentioned were not really interested in teaching speech to infants and children but in the physiology of this phenomenon (especially Aristotle) and creating the most favorable environment for the shaping of speech through the selection of nannies and child minders. There were no attempts, as Augustine aptly wrote, to teach speech consciously; it was the child himself that had to associate the sound with its material, meaningful background through observations and repeating experiences. What is more, both moral philosophers and Church Fathers described in a friendly manner (also Chrysostom) talking to children using a special, childlike language since it pleased and still pleases adults, although spoils the way children speak. The Classic Antiquity, which took care about the proper speech and promoted (like Church Fathers) rhetoric in everyday life and science, forgot about the basics, the process of creating speech, which resulted from depreciation of the first stage of children's life, condemned to contacts with slaves - nannies. It was only the school age that stirred up stronger emotions but, as some moral philosophers wrote, children already had speech defects, among others, because of parental consent for the language deprivation. 